\title{
До 7о-ліття від Дня народження професора Ігоря Яковича Дзюбановського
}

18 лютого 2021 року виповнилося 70 років завідувачу кафедри хірургії ННI післядипломної освіти ТНМУ, заслуженому діячу науки і техніки України, доктору медичних наук, професорові Ігорю Яковичу Дзюбановському.

Дзюбановський Ігор Якович народився 18 лютого 1951 р. у с. Ігровиця Тернопільського району Тернопільської області. 1974 року закінчив Тернопільський державний медичний інститут за спеціальністю “Лікувальна справа”. 1984 р. йому присуджено науковий ступінь кандидата медичних наук, 1992-го доктора медичних наук.

Ігор Якович - автор і співавтор 402 наукових та навчально-методичних робіт, 54 патентів на винахід, 9 раціоналізаторських пропозицій, співавтор 4 підручників, 7 монографій, 2 методичних рекомендацій, затверджених МОЗ України.

Під його керівництвом захищені 23 кандидатські та 3 докторські дисертації, в яких запропоновані та апробовані в практичній охороні здоров'я нові й удосконалені існуючі методи операційного лікування хворих на хірургічну патологію органів черевної порожнини.

1992 року І. Я. Дзюбановський очолив кафедру хірургії факультету удосконалення лікарів, з 1995 р. - кафедру факультетської хірургії, з 1998 р. - кафедру хірургії післядипломної освіти, із 2009 р. - кафедру хірургії з малоінвазивними ендоскопічними технологіями ФПО, з 2012 кафедру хірургії № 1, а $з 2014$ - кафедру хірургії Навчально-наукового інституту післядипломної освіти. Працюючи на посаді, проявив новаторський і творчий підхід до організації наукового і навчального процесу, підготовки лікарів-інтернів та лікарів-курсантів ФПО. Ігор Якович організував і проводив виїзні передатестаційні цикли з хірургії в Рівненській та Житомирській областях, тематичні курси удосконалення лікарів “Вибрані питання хірургії” та “Інтервенційна сонографія в невідкладній абдомінальній хірургії”.

2004 i 2007 p. І. Я. Дзюбановський провів 2 науково-практичні конференції “Актуальні питання геріатричної хірургії», 2005 р. - науково-практичну конференцію “Сучасні аспекти хірургічного лікування ускладнених форм виразкової хвороби”, 2010 р. науково-практичну конференцію з міжнародною участю "Biдеоендоскопічні методи при лікуванні хірургічної патології”, 2015 р. - науково-практичну конференцію "Нестандартні ситуації в хірургії”. 2020 р. організував науково-практичну конференцію $з$ міжнародною участю Перший Галицький хірургічний форум “Інноваційні технології в хірургії” з нагоди 100-річчя з дня народження Юрія Теофіловича Коморовського.

Щороку на базі клініки Ігор Якович проводить засідання обласної наукової асоціації хірургів, переривчасті курси навчання для хірургів області. Він - лікар-хірург вищої кваліфікаційної категоpiї. Регулярно здійснює клінічні обходи та консультації хворих у хірургічних підрозділах Тернопільської комунальної міської лікарні № 2, проводить планові консультативні та ургентні виїзди в районні лікарні області. Організував і розробив програму дистанційного навчання для інтернів-хірургів заочних баз стажування. Очолюваний професором I. Я. Дзюбановським колектив кафедри хірургії ННІ ПО 2002, 2003 та 2004 р. отримав дипломи 2 ступеня за вагомі досягнення в науковій і лікувальній роботі університету.

31993 до 2013 р. та з 2019 і донині - член спеціалізованої вченої ради з хірургії у Львівському національному медичному університеті імені Данила Галицького; до 2013 р. - заступник голови спеціалізованої вченої ради, а з 2014 р. - голова спеціалізованої вченої ради Д 58.601.01, а 3 2015 р. - знову заступник голови спеціалізованої вченої ради у Тернопільському національному медичному університеті імені І. Я. Горбачевського MO3 України із захисту докторських та кандидатських дисертацій. 31998 р. - відповідальний секретар, а з 2014 р. - головний редактор журналу "Шпитальна хірургія. Журналу імені Л. Я. Ковальчука”, член редакційної ради “Українського журналу хірургії”, "Вісника вищої медичної освіти”, 
“Acta Medica Leopoliensia”. Ігор Якович організував і провів у Тернополі VII з'їзд ВУЛТ (2003р.) та СФУЛТ (2018 p). 33 грудня 2015 р. обраний головою Асоціації хірургів Тернопільської області.

Свідченням багатогранності таланту були численні нагороди за участь у художній самодіяльності, починаючи зі студентських років.

Професор I. Я. Дзюбановський за професійну та громадську діяльність відзначений почесним званням "Заслужений діяч науки і техніки України”, подякою міністра охорони здоров'я України, стипендією Президента України, тричі - грамотою голови облдержадміністрації, медаллю “15 років ВУЛТ”, грамотами та подяками ректора університету, визнаний “Людиною року - 2007 Тернопільщини”.

Ігор Якович постійно удосконалює методики пластики пахових і гігантських післяопераційних вентральних гриж алотрансплантатами із засто- суванням ентеросорбентів, ліпосомальних антибіотиків, імунокоректорів. Розпрацьовані і впроваджені ним у клініку органощадні та органозберігальні операційні втручання при ускладнених гастродуоденальних виразках, мініінвазивні лапароскопічні, відеоендоскопічні втручання при ускладненнях некротичного панкреатиту; пункційні методи лікування кіст печінки, нирок, підшлункової залози під контролем сонографії і комп’ютерної томографії; хірургічні способи корекції морбідного ожиріння; результати вивчення синдрому ентеральної недостатності при кишковій непрохідності, маркерів пошкодження кардіоміоцитів, гепатоцитів, ентероцитів при кишковій непрохідності, панкреатиті та перитоніті.

За участю Ігоря Яковича створено центри 3 xiрургічного лікування гриж, захворювань вен нижніх кінцівок та центр рентгеноендоваскулярної хірургії.

Редакція журналу “Шпитальна хірургія. Журнал імені Л. Я. Ковальчука”, колективи кафедр хірургії ТНМУ імені І. Я. Горбачевського, вся медична громадськість області щиросердечно вітають Ігоря Яковича з 70-літтям, бажають йому міцного здоров'я, творчого натхнення, нових успіхів на благо нашого університету, медичної науки та здоров'я українського народу. 